\title{
Teacher Efficacy for Online Teaching During the COVID-19 Pandemic
}

\section{Brock Brock Education}

A journal of educational research and practice

2021 Vol. 30 (1) 95-116

https://journals.library.brocku.ca/brocked

\section{Tim Dolighan* and Michael Owen}

Brock University

\begin{abstract}
This study examines secondary teachers' efficacy for teaching in a fully online teaching environment during the sudden transition to online teaching due to the COVID-19 pandemic. The study sought to identify how specific variables, teaching experience, professional development (PD) experience, and teaching supports correlate with the self-efficacy perceptions of teachers transitioning to online teaching during a pandemic. More specifically, we examined self-efficacy perceptions of teachers in the domains of student engagement, instructional strategies, classroom management, and computer skills. The instrument used to measure teacher efficacy for online teaching was a 32-item, web-based survey that was given to Ontario secondary teachers in a southern Ontario Catholic district school board. We argue that prior experience with online learning such as additional qualification (AQ) courses or online PD would build greater self-efficacy amongst teachers as they transition to online learning. The results indicate that higher online teaching efficacy scores correlated with having taken online AQ courses and online PD sessions. The highest online teaching efficacy scores correlated with having previously used a board-provided learning management system (LMS) and using virtual technology supports. These indicators are correlated with higher scores of online teaching efficacy but require further investigation as to how they can better provide support for teachers in online learning environments.
\end{abstract}

Keywords: online teaching, self-efficacy, COVID-19 pandemic, professional development

*tim.dolighan@brocku.ca 
The challenge of doing something new usually is accompanied by apprehension and fragile confidence. Having to suddenly transition to a new teaching and learning environment, as is the case for teachers across Ontario and the world, is daunting. Online or virtual teaching and computer-based instruction are substantially different from face-to-face practice and require different teacher training and preparation (Barbour \& Unger, 2014). This study is Phase 1 of a two-phase mixed methods approach (Creswell et al., 2011; Northcote et al., 2015) identifying supports for teachers that build efficacy for online teaching. Supporting teachers in an emergency transition to online teaching has to recognize the need to support teachers' mental health and well-being by examining the impact of occupational stress on self-efficacy (Panisoara et al., 2020). This study, first, aims to measure teacher self-efficacy in the early stages of transitioning to fully online environments in the spring of 2020 in the hopes of better understanding what support and training secondary teachers will need to effectively make that transition and for ongoing professional learning and training going forward in the context of the COVID-19 pandemic and the lasting effects on education.

\section{Review of Relevant Literature}

\section{Self-Efficacy and Technology Use}

In their review of the literature of teacher self-efficacy in online education, Corry and Stella (2018) indicate that researchers agree that online and face-to-face education have different contexts and warrant examining teacher self-efficacy for online education. Much of the teacher self-efficacy measurement instruments used in online education research were based on scales that were internally validated for teachers in a face-to-face context. Most instruments were originally designed to measure pedagogical knowledge or content-specific pedagogy and few include the extensive use of technology in instruction. Research suggests there is a link between technology use in the classroom and teacher self-efficacy (Kopcha \& Alger, 2011; Mishra \& Koehler, 2006). Corry and Stella (2018) further suggest research that links selfefficacy and technology integration could be of specific importance to studying online education given the inherent role of technology in online learning environments. However, work still needs to be done to validate teacher self-efficacy measurement instruments modified for online learning.

A growing body of literature measures teachers' self-efficacy and use of technology (Angeli \& Valanides, 2009; Ertmer \& Ottenbreit-Leftwhich, 2010; Ertmer et al., 2014; Moore-Hayes, 2011 ). Eickelmann and Vennemann (2017) reviewed measurements for teacher attitudes and beliefs. The technological pedagogical content knowledge (TPCK/TPACK) framework developed by Mishra and Koehler (2006) is designed to reflect teachers' knowledge necessary for effective integration of technology in teaching. Other studies explored teachers' self-efficacy and outcome expectations with regard to integrating technology in education. Niederhauser and 
Perkmen (2010) considered self-efficacy and outcome expectations as important variables for effective teaching with technology and provided a way of assessing where teachers are before and after an intervention or professional learning experience. Perkmen (2008) found that technology integration, self-efficacy (TISE) and instructional technology outcome expectations (ITOE) constructs have mutual relationships in the prediction of technology integration performance and that participants with high self-efficacy also have high outcome expectations. Semiz and Ince (2012) examined the combination of the TPACK, TISE, and ITOE constructs with pre-service physical education teachers. The findings suggest that the significant and positive relationship of the TPACK variables with technology integration self-efficacy and ITOEs mirrors similar findings of other subjects in the literature (Angeli \& Valanides, 2009; Semiz \& Ince, 2012). Previous studies also identified intervention programs' positive influence on improving the technological pedagogical content knowledge perception of both in-service and pre-service teachers' self-efficacy for integrating technology into teaching (Angeli \& Valanides, 2009; Mishra \& Koehler, 2006).

Research also has focused on specific elements of teaching digital technology. Hatlevik and Hatlevik (2018) found that teachers' general self-efficacy for using information and communication technology (ICT) is related to their use of ICT in teaching. The authors suggest that general ICT self-efficacy is necessary for developing ICT self-efficacy for educational purposes, which is supported by other research on self-efficacy and the use of ICT for teaching (Fanni et al., 2013; Hammond, 201 1; Hatlevik, 2017; Teo, 2014). Hatlevik and Hatlevik (2018) also showed that collegial collaboration among teachers has a positive association with the use of ICT in their teaching practice. Tondeur et al. (2017) reported a promising approach to longterm professional development (PD) builds on pre-service teacher education and beliefs reinforced through ongoing collaborative inquiry. Moore-Hayes (2011) compared self-efficacy for technology integration of pre-service and in-service teachers and found a significant difference between the two groups from a quantitative perspective but noted that open-ended questions about examples from practice revealed teachers in both groups experienced feelings of low self-efficacy related to technology integration, suggesting a distinction between instructional self-efficacy and technology self-efficacy (Horvitz et al., 2015; Lin \& Zheng, 2015; Robinia \& Anderson, 2010). Engaging ongoing professional learning through summer workshops and supplemental online courses, the study found that teacher efficacy improved and remained high over the long-term versus just having a PD workshop.

Our review of the literature also suggests the need for a better understanding of barriers that prevent teachers integrating technology into their instructional practices. These barriers include lack of time, lack of resources, rigid schedules, and examination requirements that support and encourage teacher-centred approaches to use of technology (Tondeur et al., 2012). The review also revealed the importance of a multi-dimensional approach to the relationship between 
pedagogical beliefs and technology use. Research that examined barriers to teaching online in higher education found the top inhibiting factors included teachers' resistance to innovation and online teaching methods, unfamiliarity with effective online teaching pedagogy, technical concerns about reliability, the impersonal nature of online teaching, and lack of institutional support (Berge, 1998; Liu et al., 2007; Shea, 2007). Effective PD is ongoing, and continually updates and extends teachers' professional knowledge and beliefs in the context of their work (Kopcha, 2012; Sang et al., 2012; Tondeur et al., 2017). Teacher PD must enable internal changes in knowledge, attitude, and beliefs as well as an external culture of collaboration and inquiry that will foster and sustain change.

\section{Self-Efficacy and Online Teaching}

A number of studies placed teacher beliefs and self-efficacy as a primary barrier to using technology in education (Ertmer \& Ottenbteit-Leftwhich, 2010; Ertmer et al., 2014; Moore Hayes, 2011 ). Bandura (2006) provides guides for constructing self-efficacy scales that underlines self-efficacy as a main factor in achieving learning outcomes. In terms of using technology, TPACK and teacher self-efficacy are critical dimensions for ensuring effective integration of technology into education (Mishra \& Koehler, 2006). However, characteristics of teachers who use technology for professional use and who are currently immersed in transitioning to online teaching have not been examined in detail. Lee and Tsai (2010) explored teachers' self-efficacy for using the internet for teaching. They added a web component to the TPCK framework to examine correlations between self-efficacy and the TPCK-W score. Correlations with web-based teaching, self-efficacy, and positive attitudes towards the use of the internet for teaching were found.

The integration of technology into teaching has been imposed by the COVID-19 pandemic restrictions requiring teachers across Ontario and the world to teach online from home. Not only the context is different in the virtual classroom; the qualities and characteristics of the teaching and learning experiences also are different (Cho \& Shen, 2013; Rice, 2006). The skills necessary for teaching in the virtual environment are different than face-to-face instruction. These skills include managing the online classroom, creating instruction for the online platform, motivating and engaging online students, instructional design in the online environment (Jackson \& Jones, 2019; Kennedy \& Archambault, 2012), and fostering a social and learner presence in the online setting (Anderson, 2017; Garrison \& Akyol, 2013). Min-Ling Hung (2016) studied elementary and middle school teachers' readiness for teaching online using the teacher readiness for online learning measure (TROLM). The scale was comprised of four factors: communication self-efficacy, institutional support, self-directed learning, and learning-transfer self-efficacy. Results found that male teachers exhibited statistically significantly greater readiness in the dimension of learning-transfer self-efficacy than did 
female teachers. Teachers with a master's degree reported higher communication self-efficacy and learning-transfer self-efficacy than did teachers with a bachelor's degree. The study also found that teachers with fewer teaching years' experience reported higher communication selfefficacy and higher self-directed learning was reported by teachers with more years of teaching experience. A study by Lin and Zheng (2015) examined PD for online primary and secondary teachers' adjustment to online teaching. The results of the study identified a distinction between instructional self-efficacy and technology self-efficacy and showed a correlation between content-related instructional practices and instructional self-efficacy. This study as well as other studies that focused on online pedagogy supported the result of teachers' desire for technology specific PD (Horvitz et al., 2015; Robinia \& Anderson, 2010). Studying teachers' efficacy for online teaching, Corry and Stella (2018) reviewed the literature over the past 15 years on teacher self-efficacy in online education. The authors found that researchers have examined the balance of technological and pedagogical knowledge that supports the development of teacher self-efficacy, the role of learner self-efficacy, and whether teacher selfefficacy differs fundamentally in online education. Further, Corry and Stella suggest that the association of teacher self-efficacy and student success has yet to be empirically validated. The review identifies and explores three areas of research: ease of adopting online teaching; online teaching self-efficacy in comparison to demographic and experience variables; and changes in teacher self-efficacy in PD scenarios where self-efficacy was measured before and after intervention. Corry and Stella conclude that the literature supports further research investigating the construct of teacher self-efficacy in online education and possible correlations between self-efficacy and student success in the online learning environment.

\section{The Self-Efficacy for Online Teaching Instrument}

Teacher self-efficacy refers to "teachers' beliefs about their own capacity as teachers" (Tschannen-Moran et al., 1998, p. 202). Teacher efficacy has been studied extensively since the 1970s (Armor et al., 1976; Ashton et al., 1982; Berman et al., 1977; Tschannen-Moran et al., 1998). Bandura et al. (1999) defined perceived self-efficacy as a future-oriented belief in one's level of competence in a given situation. Self-efficacy beliefs are correlated with the effort people are willing to expend to attain a goal and how persistent they are in the face of adversity and recover from setbacks (Bandura, 1986, 1993). Teacher efficacy has been correlated with a number of academic and behavioural elements such as student achievement (Armor et al., 1976; Ashton \& Webb, 1986; Berman et al., 1977; Tracz \& Gibson, 1986). High teacher selfefficacy also correlates with maintaining high levels of student engagement (Good \& Brophy, 2003; Martin et al., 2012). Research also shows teacher self-efficacy is correlated with perceived work environment and job satisfaction and teachers with low self-efficacy tend to have higher stress and higher likelihood of burnout (Klassen \& Chiu, 2010). Teacher selfefficacy is also related to years of teaching experience and the level of grade taught. Teachers 
with a strong sense of self-efficacy tend to do more planning and organization and are more willing to experiment with new methods to meet the needs of their students (Stein \& Wang, 1988). Self-efficacy also influences a teacher's level of persistence and resilience in the face of setbacks (Beltman et al., 2011), which in the context of the transition to a new online learning environment seems to be a useful measure to examine. Corry and Stella (2018) advocate for research that ties together teacher self-efficacy and technology integration with online teaching and learning. While the link between teacher self-efficacy and integrating technology into the classroom is made by researchers (Kopcha \& Alger, 2011 ; Mishra \& Koehler, 2006), the role it plays in how confident teachers are teaching online is not well established. Self-efficacy measurements identified by Corry and Stella are largely adapted from scales internally validated for teachers in a face-to-face teaching environment. Corry and Stella explain that efforts to validate teacher efficacy instruments modified for online education have been made but conclude that much more effort is needed given the influence of teacher self-efficacy on student outcomes in face-to-face education. Northcote et al. (2015) used the online teaching self-efficacy inventory (OTSEI) developed by Gosselin (2009) to measure higher education instructors' self-efficacy beliefs specific to online instruction. Northcote et al. (2015) found that a multi-faceted approach to professional learning programs that focus on developing online teaching abilities and pedagogy increasingly empowers teachers in their design and delivery of online learning. Teacher self-efficacy for online teaching in all these identified areas of research are of concern in this study but with the added element of forced transition and stresses that the restrictions imposed by the pandemic produced. Using the self-efficacy measurement developed by Tschannen-Moran et al. (1998) and modified for online instructors by Robinia and Anderson (2010) provides a familiar framework of pedagogy and instruction such as student engagement and classroom management, with the inclusion of measures for technology use and online instructional strategies.

As shown above, research on teacher efficacy presents a number of instruments used in different scenarios. A review of literature did not turn up an instrument used specifically for measuring teacher self-efficacy for online teaching at the secondary level. Therefore, the teacher self-efficacy scale by Tschannen-Moran et al. (1998) was chosen, and modifications for online teaching were considered using the MNESEOT variation of the scale that measured nurse educators' efficacy for teaching online (Robinia \& Anderson, 2010). The model provided by Tschannen-Moran et al. (1998) emphasizes the strong cyclical nature of teacher efficacy, which is enhanced by mastery experiences encouraging greater effort, persistence, and performance on task. Both Robinia and Anderson (2010) and Horvitz et al. (2015) found similar results with nursing faculty who had more experience teaching online courses reporting higher selfefficacy, which suggested experience teaching online could impact self-efficacy.

Ontario teachers, along with hundreds of thousands of teachers worldwide, transitioned to 
online teaching environments in spring 2020 as a response to the COVID-19 pandemic. A study of teacher efficacy for online teaching presents an opportunity to better understand where teachers are in terms of confidence for teaching online and how to better support teachers in an unprecedented transitional phase. Given the challenges faced by secondary teachers during the spring 2020 school term due to the requirement to transition from face-to-face to an online learning environment, Tschannen-Moran et al. (1998), as modified by Robinia and Anderson (2010), guided the development of our research questions and hypotheses.

\section{Research Questions}

This study sought to measure and understand teacher efficacy in the early stages of transitioning from face-to-face to fully online environments. We argue that prior experience with online learning including online Additional Qualification (AQ) courses ${ }^{1}$ and/or online PD would build greater self-efficacy amongst teachers as they transition to online learning. We also argue that having support from technical support teams (e.g., IT support, instructional designers) and knowledge of the school district's learning management system (LMS) supported teachers' positive efficacy. More specifically, we asked the following research questions:

1. How confident do secondary teachers feel in preparing, conducting, and evaluating online courses?

2. Is there a difference in online teaching efficacy in relation to: (a) age, (b) gender, (c) years of face-to-face teaching experience, and (d) years of online teaching experience?

3. In what ways do experience with online teaching, PD, and perceived support from experts or instructional designers influence teachers' reported self-efficacy for online teaching?

We therefore hypothesize that:

- There will be a positive relationship between levels of online teaching efficacy and (a) years of online teaching experience and/or (b) number of online teaching experiences.

- Teachers who have participated in online AQ experiences for (a) teaching in general and/or (b) online teaching will have significantly higher levels of online teaching efficacy.

- Teachers who report experiences of expert and/or instructional designer support contacts will have significantly higher levels of online teaching efficacy.

1 Additional Qualification (AQ) courses are courses accredited by the Ontario College of Teachers (OTC) that qualified teachers can take to upgrade knowledge and skills and gain qualifications in a certain teaching division or subject (OCT, 2021). 
- Teachers who report taking online PD courses or seminars for online teaching will have significantly higher levels of online teaching efficacy.

- Teachers who report using board-provided online teaching platform (D2L or EDSBY) prior to the transition to online will have significantly higher levels of online teaching efficacy.

- Teachers who use virtual technology support for online teaching will have significantly higher levels of online teaching efficacy.

\section{Methods}

Sample population was determined based on access to secondary teachers at a Catholic school district in southern Ontario. Following ethics approval from the school district and Brock University, emails were sent to all secondary teachers inviting them to complete a web-based survey using Microsoft forms. Out of 432 secondary teachers employed at the board, 132 responded; $61 \%$ are female, the average age was $48,73 \%$ had a bachelor's degree (e.g., B.A. or B.Sc. plus/or B.Ed.) and $70 \%$ have been teaching for 16 or more years in public education. Eighty-one percent of respondents reported teaching 5 or less years online. Of those who reported $\leq 5$ years' experience teaching online, $88 \%$ (or $71.3 \%$ of respondents) reported 1 year or less online teaching experience.

The survey was a digital survey developed using Microsoft forms and based on the Michigan nurse educators sense of efficacy for online teaching (MNESEOT) instrument (Robinia \& Anderson, 2010). The survey consisted of 32 questions that asked participants to rate their perceived self-efficacy for online teaching on a Likert scale of 1-9 (1 being "nothing" and 9 being "a great deal"). The mean for each subscale (student engagement, classroom management, online instruction, and use of computers) was calculated and added together to produce a total mean score. Across the entire survey, participants' mean score was 22.06 with a standard deviation of 4.38 across a scale of $4-36$. Without a standard to measure against, it is difficult to say how teachers compared to the secondary school teacher population in Ontario, so all measures are determined within and between the one survey.

The instrument used showed a Cronbach alpha of .951 with this sample $(n=132)$, changes to the MNESEOT were made to some of the questions to reflect secondary teachers' experience with online teaching. Online pedagogies and strategies for online teaching were considered based on the signature pedagogies for e-learning by Eaton et al. (2017).

\section{Process for Data Collection}

Demographic questions were asked to identify variables that may or may not impact efficacy ratings. Teachers were also asked about the value of online AQ courses, seminars, and PD for online instruction, the use of expert help, and virtual support for teaching online. 


\section{Data Analysis}

Study questions were addressed by calculating means and standard deviations of the teacher sense of efficacy for online teaching survey (TSEOT) scores (Horvitz et al., 2015; Robinia \& Anderson, 2010; Tschannen-Moran et al., 2001) for the four measures: student engagement, classroom management, online instruction strategies, and computer skills. The Pearson correlation coefficient was used to determine relationships between interval variables. Analysis of variance (ANOVA) was used to assess differences of means of online teaching efficacy scores. An alpha of .05 was used for all tests.

\section{Ethics Approval}

The study was reviewed and approved by the research ethics board (REB) of the school board and Brock University. The use of Microsoft forms allowed for secure submission of surveys and for the researchers to anonymize the data. Respondents were asked not to include any identifying marks or information within the text options of the survey.

\section{Results}

The survey consisted of 32 questions that asked participants to rate their perceived selfefficacy on a Likert scale of 1-9 (1 being "nothing" and 9 being "a great deal"). The mean for each subscale (student engagement, classroom management, online instruction, and use of computers) was calculated and added together to produce a total mean score. Across the entire survey, participants' mean score was 22.06 with a standard deviation of 4.38 across a scale of 4-36. Overall, teachers surveyed believed they could do "very little" to "some" with regards to preparing, teaching, and evaluating online courses.

Table 1

Total TSEOT Scores

\begin{tabular}{lccc}
\hline Total TSEOT score $(\mathrm{n}=132)$ & Mean & SD & Range \\
\hline Student engagement & 4.73 & 1.13 & 1 to 9 \\
Instructional strategies & 5.76 & 0.77 & 1 to 9 \\
Classroom management & 5.35 & 0.83 & 1 to 9 \\
Computer skills & 6.23 & 1.65 & 1 to 9 \\
Total TOETS score & 22.06 & 4.38 & $4-36$ \\
\hline
\end{tabular}

An independent t-test showed no significant difference between males, $n=46(M=22.04$, $\mathrm{SD}=4.37)$ and females, $\mathrm{n}=80(\mathrm{M}=22.07, \mathrm{SD}=4.36), \mathrm{p}=0.40$ (two-tail). 
The Pearson product moment correlation revealed no significant relationship between the variables of age, highest degree, years teaching online, years teaching face to face, and TESEOT scores. Significant correlations (2-tailed) were found with having taken an online AQ $(r=.180$, $p=.039)$; doing PD sessions for online teaching $(r=.262, p=.002)$; the number of PD sessions $(r=.194, p=.028)$; using a board LMS $(r=.248, p=.004)$; using virtual tech support $(r=.291$, $\mathrm{p}=.001$ ), with the dependent variable measure of the TSEOT scores.

\section{Table 2}

\section{Pearson Correlation Matrix}

\begin{tabular}{|c|c|c|c|c|c|c|c|c|c|c|c|c|}
\hline Correlations & & & & & & & & & & & & \\
\hline & & 1 & 2 & 3 & 4 & 5 & 6 & 7 & 8 & 9 & 10 & 11 \\
\hline \multirow[t]{2}{*}{ TEOTS score } & Pearson Correlation & 1 & & & & & & & & & & \\
\hline & $\mathrm{N}$ & 132 & & & & & & & & & & \\
\hline \multirow[t]{3}{*}{ Yrs Teaching Online } & Pearson Correlation & 0.038 & 0.161 & & & & & & & & & \\
\hline & Sig. (2-tailed) & 0.662 & 0.067 & & & & & & & & & \\
\hline & $\mathrm{N}$ & 132 & 131 & & & & & & & & & \\
\hline \multirow[t]{3}{*}{ \# of yrs Teaching online } & Pearson Correlation & 0.086 & 0.075 & 1 & & & & & & & & \\
\hline & Sig. (2-tailed) & 0.328 & 0.395 & & & & & & & & & \\
\hline & $\mathrm{N}$ & 132 & 131 & 129 & & & & & & & & \\
\hline \multirow[t]{3}{*}{ Yrs teaching F2F } & Pearson Correlation & -0.04 & -0.055 & 0.246 & 1 & & & & & & & \\
\hline & Sig. (2-tailed) & 0.651 & 0.53 & 0.005 & & & & & & & & \\
\hline & $\mathrm{N}$ & 132 & 131 & 129 & 132 & & & & & & & \\
\hline \multirow[t]{3}{*}{ Taken Online AQ } & Pearson Correlation & $0.180^{*}$ & 0.082 & 0.134 & 0.03 & 1 & & & & & & \\
\hline & Sig. (2-tailed) & 0.039 & 0.353 & 0.131 & 0.73 & & & & & & & \\
\hline & $\mathrm{N}$ & 132 & 131 & 129 & 132 & 132 & & & & & & \\
\hline \multirow[t]{3}{*}{ \# of online AQs } & Pearson Correlation & 0.059 & 0.144 & -0.03 & -0.002 & 0.436 & 1 & & & & & \\
\hline & Sig. (2-tailed) & 0.506 & 0.105 & 0.732 & 0.979 & 0 & & & & & & \\
\hline & $\mathrm{N}$ & 129 & 128 & 129 & 132 & 132 & 132 & & & & & \\
\hline \multirow{3}{*}{ PD for online teaching } & Pearson Correlation & $0.262 * *$ & 0.233 & 0.526 & -0.018 & 0.193 & 0.131 & 1 & & & & \\
\hline & Sig. (2-tailed) & 0.002 & 0.007 & 0 & 0.837 & 0.026 & 0.134 & & & & & \\
\hline & $\mathrm{N}$ & 132 & 131 & 129 & 132 & 132 & 132 & 132 & & & & \\
\hline \multirow[t]{3}{*}{ \# PD sessions For OT } & Pearson Correlation & $0.194 *$ & 0.205 & 0.132 & 0.262 & 0.069 & -0.044 & -0.015 & 1 & & & \\
\hline & Sig. (2-tailed) & 0.028 & 0.02 & 0.137 & 0.002 & 0.433 & 0.618 & 0.865 & & & & \\
\hline & $\mathrm{N}$ & 129 & 128 & 129 & 132 & 132 & 132 & 132 & 132 & & & \\
\hline \multirow[t]{3}{*}{ Used Expert help } & Pearson Correlation & 0.149 & 0.167 & -0.02 & 0.24 & 0.169 & 0.051 & -0.055 & 0.383 & 1 & & \\
\hline & Sig. (2-tailed) & 0.089 & 0.056 & 0.827 & 0.006 & 0.056 & 0.565 & 0.537 & 0 & & & \\
\hline & $\mathrm{N}$ & 132 & 131 & 126 & 129 & 129 & 129 & 129 & 129 & 129 & & \\
\hline \multirow[t]{3}{*}{ Using board (LMS) } & Pearson Correlation & $0.248^{* *}$ & 0.029 & -0.083 & 0.086 & 0.008 & 0.08 & -0.036 & 0.319 & 0.238 & 1 & \\
\hline & Sig. (2-tailed) & 0.004 & 0.741 & 0.349 & 0.328 & 0.924 & 0.362 & 0.681 & 0 & 0.007 & & \\
\hline & $\mathrm{N}$ & 131 & 130 & 129 & 132 & 132 & 132 & 132 & 132 & 129 & 132 & \\
\hline \multirow[t]{3}{*}{ Used virtual tech support } & Pearson Correlation & $0.291 * *$ & 0.068 & -0.024 & 0.101 & 0.064 & 0.205 & 0.029 & 0.215 & 0.445 & 0.571 & \\
\hline & Sig. (2-tailed) & 0.001 & 0.437 & 0.787 & 0.255 & 0.471 & 0.02 & 0.741 & 0.014 & 0 & 0 & \\
\hline & $\mathrm{N}$ & 132 & 131 & 126 & 129 & 129 & 129 & 129 & 129 & 127 & 129 & 12 \\
\hline
\end{tabular}

Although the data showed a significant correlation between having taken an online AQ course that supported online teaching, $(r=.180, p=.039)$, the data did not support any significant correlation between number of online AQs taken with higher efficacy scores. Participants were asked to rate the value of taking online AQ courses, the value of taking PD for online teaching, and how well virtual tech support prepares for online teaching on a Likert scale of 1-5. The mean response for the value online $A Q$ courses provide was 2.78 (Disagree to Neutral). The mean response for the value of taking PD for online teaching was 3.5 (Neutral to Agree) and the mean score for the value of virtual tech support for online teaching is 3.31 (Neutral). 
Mean scores for the subscales were calculated: student engagement $(M=4.70, S D=1.28)$, class management $(M=5.30, S D=1.36)$, instructional strategies $(M=5.74, S D=1.39)$, computer skills $(M=6.16, S D=1.31)$. Paired sample correlations revealed significant relationships between all pairs. A paired samples t-test was performed to look closer at paired differences. Significant differences were found in the scores for student engagement $(M=4.70, S D=1.28)$ and computer skills $(M=6.16, S D=1.31)$ conditions; $t(131)=-14.98, p=<.001$. Student engagement $(M=4.70$, $S D=1.28)$ and instructional strategies $(M=5.74, S D=1.39)$ conditions; $t(131)=-14.77$, $\mathrm{p}=<.001$ also revealed significant differences.

Table 3

Paired Samples t-Test

\begin{tabular}{|c|c|c|c|c|c|c|c|c|c|}
\hline \multicolumn{7}{|c|}{ Paired Differences } & \multirow[b]{3}{*}{$t$} & \multirow[b]{3}{*}{ df } & \multirow[b]{3}{*}{ Sig. (2-tailed } \\
\hline & & \multirow[b]{2}{*}{ Mean } & \multirow[b]{2}{*}{ Std. Deviation } & \multirow{2}{*}{$\begin{array}{l}\text { Std. Error } \\
\text { Mean }\end{array}$} & \multicolumn{2}{|c|}{$\begin{array}{l}\text { 95\% Confidence Interval of the } \\
\text { Difference }\end{array}$} & & & \\
\hline & & & & & Lower & Upper & & & \\
\hline Pair 1 & $\begin{array}{l}\text { Student engagement- } \\
\text { Instructional Strategies }\end{array}$ & -1.039773 & .808813 & .070398 & -1.179037 & -.900508 & -14.770 & 131 & .000 \\
\hline Pair 2 & $\begin{array}{l}\text { Student engagement- } \\
\text { Class Management }\end{array}$ & -.589015 & .960644 & .083613 & -.754422 & -.423608 & -7.045 & 131 & .000 \\
\hline Pair 3 & $\begin{array}{l}\text { Student engagement- } \\
\text { Comp Skills }\end{array}$ & -1.461174 & 1.120393 & .097518 & -1.654087 & -1.268261 & -14.984 & 131 & .000 \\
\hline Pair 4 & $\begin{array}{l}\text { Comp Skills - } \\
\text { Instructional Strategies }\end{array}$ & .421402 & 1.024672 & .089186 & .244970 & .597833 & 4.725 & 131 & .000 \\
\hline Pair 5 & $\begin{array}{l}\text { Comp Skills - Class } \\
\text { Management }\end{array}$ & .872159 & 1.142461 & .099438 & .675446 & 1.068872 & 8.771 & 131 & .000 \\
\hline Pair 6 & $\begin{array}{l}\text { Class Management- } \\
\text { Instructional Strategies }\end{array}$ & -.450758 & 1.085201 & .094455 & -.637611 & -.263904 & -4.772 & 131 & .000 \\
\hline
\end{tabular}

\section{Hypothesis Findings}

1. The data did not support a significant positive relationship between levels of online teaching efficacy and (a) years of online teaching experience and/or (b) number of online teaching experiences.

2. The correlation between taking an online $A Q$ course and higher teacher efficacy for online teaching was significant for $\mathrm{p}<.05$.

3. Teachers who reported taking online PD courses or seminars for online teaching had significantly higher levels of online teaching efficacy. However, the data did not support a significant difference between the number of courses taken and higher efficacy scores.

4. Using expert instructional help for online teaching also showed no significant relationship to higher efficacy for teaching online.

5. Teachers who reported using board-provided online teaching platform (D2L or EDSBY) prior to the transition to online had significantly higher $\mathrm{p}<.01$ levels of online teaching efficacy. 
6. Finally, the data supported a strong correlation $\mathrm{p}<.01$ between teachers who reported using virtual technology support for online teaching and higher levels of online teaching efficacy.

\section{Discussion}

Studying teacher efficacy is challenging no matter the context. The particular context of this study further complicates the interpretation of the data. The rapid closure of Ontario schools and transition to online learning due to the COVID-19 pandemic in March 2020 offered an opportunity to study secondary teacher efficacy as they made the transition to online teaching in unique circumstances. This study surveyed teachers at the beginning of the transition $(<3$ months) in order to better understand some of the initial difficulties and challenges secondary teachers faced with transitioning to online teaching environments. This exploratory study provides a base for larger randomized samples across Ontario that could help teachers and boards overcome obstacles associated with lower self-efficacy and negative experiences. As Ontario and other Canadian jurisdictions assess a 2020-2021 school year that is substantially or completely online or in a blended mode, a school year that may be more complex in the way in which students and teachers experience the learning environment, ${ }^{2}$ understanding how teachers experienced the spring 2020 transition will provide opportunities to support teachers' sense of efficacy, thereby improving the effectiveness of instruction across all modalities.

The majority of respondents (96.2\%) reported having 11 or more years of face-to-face teaching experience $(n=127)$. However, this level of experience did not translate into efficacy for online teaching. The overall mean of TSEOT scores $(M=22.06, S D=4.38)$ indicates a lower online teaching efficacy score for the survey sample in terms of teachers reporting they feel they could do between "very little" to "some" online instruction. There is no comparable sample of secondary teachers transitioning to online teaching in any literature reviewed. Yet, studies with nursing faculty reported experience teaching online showed correlation with higher selfefficacy. One of the major differences in the populations may be that similar samples across Ontario or elsewhere would have similar efficacy scores and there are a number of demographic limitations to studying just one school board. Access to internet and technology devices may not be the same across school boards in Ontario or even within the Greater Toronto region in

2 To respond to the ongoing COVID-19 for a return to school in the fall, the Ontario Ministry of Education (2020) has outlined "three models of instruction for the 2020-2021 school year: conventional delivery, adapted instruction, and remote instruction, bolstered by live, dynamic synchronous learning" (Quick Facts section, para. 1). 
which the population worked. The diversity of the population and rural versus urban differences may present very different access to required internet and technology devices.

While we hypothesized otherwise, the findings indicate that having taught online courses did not translate into significantly higher efficacy for teaching online $(n=54, M=23.21, S D=4.78)$ compared to the sample $(n=132, M=22.06, S D=4.38), r=.086, p=.662$. Horvitz et al. (2015) reported future interest in teaching online was found to be a significant predictor of overall self-efficacy but only in the subscale of online student engagement. It would be worth investigating how many teachers had a future interest in teaching online prior to or at the time of transition to online due to the pandemic. In the same study, Horvitz et al. (2015) identified perception of student learning as a predictor of three of the four subscales. Although perception of student learning is unknown, given the highest variance result in this current study between the subscales of student engagement and computer skills and student engagement and instructional strategies there is the possibility that even though participants reported having experience teaching online courses that efficacy may have been affected by perception of student learning. During the transition to online learning, school boards across Ontario, guided by the Ministry of Education, employed measures such as cancelling final exams and marks that would not fall below reported midterm marks (Pringle, 2020). Although not supported in this study, the cyclical nature of efficacy presented by Tschannen-Moran et al. (1998) argues that more experience produces a greater sense of being capable and confidence in one's abilities. The added stress and anxiety on teachers due to an imposed transition to online could be responsible for lower positive intrinsic motivation as factors that were beyond the teachers' ability to control impacted self-efficacy for teaching online but would need to be investigated further. There is a possibility that some of the data may be influenced by other factors produced by the pandemic that are not yet understood.

The significant correlation $(\mathrm{p}<.05)$ between efficacy for teaching online and taking an online AQ course indicates that this is an area that could be explored further. The data did not show a relationship between efficacy for teaching online and the number of online AQ courses taken. This outcome could suggest that online AQ courses vary in their focus and design with regards to developing skills needed for online teaching and learning or that taking more AQ courses as a "student" does not develop skills needed to teach online. Although there is an AQ course that specifically deals with e-learning, this study did not explore whether respondents took that course and what the impact on teacher efficacy to teach online might be. All other online AQ courses could still emphasize subject content and face-to-face teaching pedagogy and assessment. The neutral satisfaction rating by teachers who were asked about the value of online AQ courses suggests more emphasis is needed to integrate and support online teaching and learning. 
As hypothesized, teachers who reported taking PD seminars or courses for online teaching had significantly higher efficacy scores. Providing formal PD opportunities that are specific to instructional challenges and designed for online teaching or the integration of technology into teaching gives teachers the opportunity to inquire and collaborate with other teachers and develop skills that are unique to teaching and learning online. The community of inquiry (COI) model of online learning (Akyol \& Garrison, 2010; Garrison \& Akyol, 2013) would provide a platform for PD sessions that builds on teacher pedagogical and content knowledge and extend teaching presence into the digital space. Blayone et al. (2017) see the technical, informational, social, and epistemological/computational dimensions and associated competencies as part of the learning process. Teaching online is more than transferring classroom practice to video screens or chat rooms.

Supporting teachers' personalized learning needs with immediate and direct application to the classroom is necessary for sustained ongoing professional learning (Hall \& Trespalacios, 2019; Koellner \& Jacobs, 2015 ; Schnackenberg \& Still, 2014). The survey data indicate that access to virtual technology support that is less formal and accessible immediately to teachers as they encounter challenges predicts higher efficacy for online teaching. Virtual technology support also allows learners to choose the support they need from the videos and examples provided, learn at their own pace, and go back and review areas of difficulty. Virtual support could include chat rooms and access to IT support in real time. Given that the overall efficacy for online teaching scores seemed somewhat low, it makes sense that immediate and accessible support that teachers can access as they encounter challenges and were able to overcome the challenge would contribute to a higher sense of cyclical efficacy identified by Tschannen-Moran et al. (1998). Since this study measured teachers' self-reported efficacy at the beginning of the imposed transition to online teaching, immediate and accessible support that could be accessed as teachers encounter challenges in the transition had a positive enabling effect. Further study on which virtual support materials were most helpful and could provide ongoing support for continued development of skills needed for effective online teaching is required.

The data support a strong correlation significant at $p<.01$ (2-tailed) for use of a learning management systems (LMS) prior to transitioning to fully online. There are several possibilities for this relationship. Teachers using the board-provided LMS would have already been working with students in an online environment, would have familiar routines, and had developed expectations that transferred to the fully online environment. Both teacher and student familiarity with the applications and expectations contributed to teachers' sense of efficacy for some of the subscale areas such as instructional strategies, online classroom management, and use of computer skills. Several teachers in the study, for example, indicated they had used the LMS for flip classroom and blended learning. 
Finally, analyzing the data from the overall mean scores of subscales revealed the highest correlation and variation between student engagement and computer skills and student engagement and instructional strategies. This strong relationship suggests resources for online teaching professional learning for teachers should focus on strategies to develop and facilitate student engagement as well as support online computer skills and instructional strategies for teachers who are transitioning to teaching in an online teaching environment. Collaborative inquiry focuses on the needs of the learner and engages the learner by employing a learnerdriven approach through collaborative knowledge construction (van Oostveen et al., 2018). According to Akyol and Garrison (2010), interaction and collaboration in an online learning environment are important elements in the learning process that supports a constructivist view of learning. van Oostveen et al. (2018) argue that a learner-centred collaborative online learning environment (COLE) model for teacher PD has the potential to change teachers' beliefs about learning by changing the online learning experience for teachers and facilitating constructivist aspects of learning and providing an opportunity to experience new pedagogies that challenge traditional notions of teaching and support the development of effective online teaching strategies. Tondeur et al. (2017) suggest long-term PD should build on pre-service teacher education and beliefs reinforced through ongoing collaborative inquiry.

\section{Limitations}

There are a number of limitations to this study that are important to note. The first and most obvious is the effect the pandemic had on teachers' and students' anxiety and stress levels as well as their reported sense of isolation and detachment from the familiar and supportive environment of a school community. Panisoara et al. (2020) studied the influence of emotional and motivational experiences on their continuance intention $(\mathrm{Cl})$ to teach online during the COVID-19 pandemic. The study highlighted significant links between cognitive-affective factors in an unstable work context including intrinsic motivation influences, occupational stress, $\mathrm{Cl}$ for online teaching, burnout, and technostress. Panisoara et al. (2020) found that teachers used digital resources but were concerned with the content knowledge associated with their field in order to do their job. According to Panisoara and colleagues, teachers perceived teaching as an obligation rather than an intrinsic desire to teach. Given the uncontrollable workplace, teachers responded by controlling what they could regarding the stress of imposed online teaching. Further study on the impact stress and anxiety from imposed teaching online on teacher selfefficacy for online teaching needs to be explored.

Our results may not be generalizable beyond the sample population. The study sample of secondary teachers within one board may not be reflective of secondary teachers, let alone all teachers across Ontario or even more broadly. The primary researcher's relationship to other secondary teachers in the board as a fellow teacher may have contributed to respondent bias 
already inherent to self-reporting. Although anonymity was provided for respondents, many respondents may know the researcher and participated for that reason rather than reflecting a true random sample.

The data collected reflect the initial stages of teachers' self-efficacy for teaching in a new online environment during a period of uncertainty and shifting direction from the Ministry of Education as the response to the pandemic unfolded. While it is unclear what teacher confidence for online teaching would be like as education resumes in whatever form it takes, the transition to using online learning environments will continue and teachers will have to be supported. Further study that measures efficacy for online teaching and considers teacher perception of student learning and desire to teach online would be useful in ongoing efforts to support teachers and student learning.

\section{Conclusion}

The need to develop online learning has become a priority for elementary and secondary schools in Ontario and internationally. Although many teachers hope for a return to the classroom and normalcy, the reality is that education has changed, and online learning will be an integral part of secondary education. Online skills for instruction and design of online learning environments are and will be an important aspect of teacher pre-service or initial teacher education and ongoing teacher professional learning. Understanding that in-service teachers need the resources and training to transition to online teaching can start with providing access to virtual tech support and ongoing support for using LMS as part of their day-to-day teaching. PD also needs to look long term, providing teachers with the means to design and provide meaningful and engaging learning experiences for students in online learning environments. Archambault and Kennedy (2014) and other researchers (e.g., Davis \& Rose, 2007; Lowes, 2007) advocate for specific teacher preparation in the areas of online pedagogy and student support strategies. The authors point out the need for longitudinal studies of pre-service preparation for K-12 online learning programs. With the reality of a new need for designing and implementing effective online learning environments, teacher PD and ongoing professional learning will have to adapt to better support the new reality.

\section{References}

Akyol, Z., \& Garrison, D. R. (2010). Community of inquiry in adult online learning: Collaborative-constructivist approaches. In Web-based education: Concepts, methodologies, tools and applications (pp. 474-489). IGI Global.

Anderson, T. (2017, September). How communities of inquiry drive teaching and learning in the digital age. Contact North. https://tinyurl.com/y68789b9 
Angeli, C., \& Valanides, N. (2009). Epistemological and methodological issues for the conceptualization, development, and assessment of ICT-TPCK: Advances in technological pedagogical content knowledge (TPCK). Computers \& Education, 52(1), 154-168. https://doi.org/10.1016/j.compedu.2008.07.006

Archambault, L., \& Kennedy, K. (2014, January). Teacher preparation for K-12 online and blended learning. In K. Kennedy \& R. E. Ferdig (Eds.), Handbook of research on $\mathrm{K}-12$ online and blended learning (pp. 225-244). ETC Press.

Armor, D., Conry-Oseguera, P., Cox, M., King, N., McDonnell, L., Pascal, A., Pauly, E., \& Zellman, G. (1976). Analysis of the school preferred reading program in selected Los Angeles minority schools. Rand.

https://www.rand.org/content/dam/rand/pubs/reports/2005/R2007.pdf

Ashton, P. T., Olejnik, S., Crocker, L., \& McAuliffe, M. (1982, September). Measurement problems in the study of teachers' sense of efficacy [Paper presentation]. American Educational Research Association Annual Meeting, New York, NY, United States.

Ashton, P. T., \& Webb, R. B. (1986). Making a difference: Teachers' sense of efficacy and student achievement. Addison-Wesley Longman.

Bandura, A. (1986). Social foundations of thought and action: A social cognitive theory. Prentice-Hall.

Bandura, A. (1993). Perceived self-efficacy in cognitive development and functioning. Educational Psychologist, 28(2), 117-148. https://doi.org/10.1207/s15326985ep2802_3

Bandura, A. (2006). Guide for constructing self-efficacy scales. In F. Pajares \& T. Urdan (Eds.), Self-efficacy beliefs of adolescents (Vol. 5, pp. 307-337). Information Age.

Bandura, A., Freeman, W. H., \& Lightsey, R. (1999). Self-efficacy: The exercise of control. Journal of Cognitive Psychotherapy, 13(2), 158-166. https://doi.org/10.1891/08898391.13 .2 .158

Barbour, M. K., \& Unger, K. L. (2014). Strategies for overcoming common obstacles in the online environment: Issues in virtual school teaching. In A. A. Piña \& A. P. Mizell (Eds.), Real life distance education: Case studies in practice (pp. $21-40$ ). Information Age.

Beltman, S., Mansfield, C., \& Price, A. (2011). Thriving not just surviving: A review of research on teacher resilience. Educational Research Review, 6(3), 185-207. https://doi.org/10.1016/j.edurev.2011.09.001

Berge, Z. L. (1998). Barriers to online teaching in post-secondary institutions: Can policy changes fix it? Online Journal of Distance Learning Administration, 1(2). https:/ /www.westga.edu/ distance/ojdla/summer12/berge12.pdf 
Berman, P., McLaughlin, M., Bass, G., Pauly, E., \& Zellman, G. (1977). Federal programs supporting education change. Vol. VII: Factors affecting implementation and continuation. Rand. https://www.rand.org/pubs/reports/R1589z7.html

Blayone, T. J. B., vanOostveen, R., Barber, W., DiGiuceppe, M., \& Childs, E., (2017). Democratizing digital learning: Theorizing the fully online learning community model. International Journal of Educational Technology in Higher Education, 14, Art. 13. https://doi.org/10.1186/s41239-017-0051-4

Cho, M-H., \& Shen, D. (2013). Self-regulation in online learning. Distance Education, 34(3), 290-301. https://doi.org/10.1080/01587919.2013.835770

Corry, M., \& Stella, J. (2018). Teacher self-efficacy in online education: A review of the literature. Research in Learning Technology, 26. https://doi.org/10.25304/rlt.v26.2047

Creswell, J. W., Klassen, A. C., Plano Clark, V. L., \& Smith, K. C. (2011). Best practices for mixed methods research in the health sciences. National Institutes of Health. https://obssr.od.nih.gov/training/online-training-resources/mixed-methods-research/

Davis, N., \& Rose, R. (2007). Research committee issues brief: Professional development for virtual schooling and online learning. NACOL. https://files.eric.ed.gov/fulltext/ED509632.pdf

Eaton, S. E., Brown, B., Schroeder, M., Lock, J., \& Jacobsen, M. (2017). Signature pedagogies for e-learning in higher education and beyond. University of Calgary. https:/ / prism.ucalgary.ca/handle/1880/51848

Eickelmann, B., \& Vennemann, M. (2017). Teachers' attitudes and beliefs regarding ICT in teaching and learning in European countries. European Educational Research Journal, 16(6), 733-761. https://doi.org/10.1177\%2F1474904117725899

Ertmer, P. A., \& Ottenbreit-Leftwich, A. T. (2010). Teacher technology change: How knowledge, confidence, beliefs, and culture intersect. Journal of Research on Technology in Education, 42(3), 255-284. https://doi.org/10.1080/15391523.2010.10782551

Ertmer, P. A., Ottenbreit-Leftwich, A. T., \& Tondeur, J. (2014). Teachers' beliefs and uses of technology to support 21 st-century teaching and learning. In H. Fives \& M. G. Gill (Eds.), International handbook of research on teachers' beliefs (pp. 403-418). Routledge.

Fanni, F., Rega, I., \& Cantoni, L. (2013). Using self-efficacy to measure primary school teachers' perception of ICT: Results from two studies. International Journal of Education and Development Using Information and Communication Technology, 9(1), 100-111. https:/ / files.eric.ed.gov/fulltext/EJ1071345.pdf

Garrison, D. R., \& Akyol, Z. (2013). The community of inquiry theoretical framework. In M. G. Moore (Ed.), Handbook of distance education (3rd ed., pp. 104-120). Routledge.

Good, T. L., \& Brophy, J. E. (2003). Looking in classrooms (9th ed.). Allyn \& Bacon. 
Gosselin, K. P. (2009). Development and psychometric exploration of the online teaching selfefficacy scale [Doctoral dissertation, Texas Tech University]. TTU DSpace. https://ttuir.tdl.org/handle/2346/8971

Hall, A. B., \& Trespalacios, J. (2019). Personalized professional learning and teacher selfefficacy for integrating technology in K-12 classrooms. Journal of Digital Learning in Teacher Education, 35(4), 221-235. https://doi.org/10.1080/21532974.2019.1647579

Hammond, M. (2011). Beliefs and ICT: What can we learn from experienced educators? Technology, Pedagogy and Education, 20(3), 289-300. https:/ / doi.org/10.1080/1475939X.2011.610930

Hatlevik, I. K., \& Hatlevik, O. E. (2018). Examining the relationship between teachers' ICT selfefficacy for educational purposes, collegial collaboration, lack of facilitation and the use of ICT in teaching practice. Frontiers in Psychology, 9(935). https:// doi.org/10.3389/fpsyg.2018.00935

Hatlevik, O. E. (2017). Examining the relationship between teachers' self-efficacy, their digital competence, strategies to evaluate information, and use of ICT at school. Scandinavian Journal of Educational Research, 67(5), 555-567. https://doi.org/10.1080/00313831.2016.1172501

Horvitz, B. S., Beach, A. L., Anderson, M. L., \& Xia, J. (2015). Examination of faculty self-efficacy related to online teaching. Innovative Higher Education, 40(4), 305-316. https:/ / doi.org/10.1007/s10755-014-9316-1

Hung, M-L. (2016). Teacher readiness for online learning: Scale development and teacher perceptions. Computers \& Education, 94, 120-133. https://doi.org/10.1016/j.compedu.2015.11.012

Jackson, B. L., \& Jones, M. (2019). Where the rubber meets the road: Exploring the perceptions of in-service teachers in a virtual field experience. Journal of Research on Technology in Education, 51(1), 7-26. https://doi.org/10.1080/15391523.2018.1530622

Kennedy, K., \& Archambault, L. (2012). Design and Development of Field Experiences in Online Learning Environments. Journal of Applied Instructional Design, 2(1), 35-49. https:/ / doi.org/10.1177/0022487111433651

Klassen, R. M., \& Chiu, M. M. (2010). Effects on teachers' self-efficacy and job satisfaction: Teacher gender, years of experience, and job stress. Journal of Educational Psychology, 102(3), 741-756. https://doi.org/10.1037/a0019237

Koellner, K., \& Jacobs, J. (2015). Distinguishing models of professional development: The case of an adaptive model's impact on teachers' knowledge, instruction, and student achievement. Journal of Teacher Education, 66(1), 51-67. https://doi.org/10.1177\%2F0022487114549599 
Kopcha, T. J. (2012). Teachers' perceptions of the barriers to technology integration and practices with technology under situated professional development. Computers \& Education, 594), 1109-1121. https://doi.org/10.1016/j.compedu.2012.05.014

Kopcha, T. J., \& Alger, C. (2011). The impact of technology-enhanced student teacher supervision on student teacher knowledge, performance, and self-efficacy during the field experience. Journal of Educational Computing Research, 45(1), 49-73. https://doi.org/10.2190\%2FEC.45.1.c

Lee, M. H., \& Tsai, C. C. (2010). Exploring teachers' perceived self efficacy and technological pedagogical content knowledge with respect to educational use of the World Wide Web. Instructional Science, 38(1), 1-21. https://doi.org/10.1007/s1 1251-008-9075-4

Lin, C. H., \& Zheng, B. (2015). Teaching practices and teacher perceptions in online world language courses. Journal of Online Learning Research, 1(3), 275-303. https:/ /www.learntechlib.org/primary/p/171055/

Liu, X., Magjuka, R. J., Bonk, C. J., \& Lee, S. H. (2007). Does sense of community matter? An examination of participants' perceptions of building learning communities in online courses. Quarterly Review of Distance Education, 8(1), 9-24.

Lowes, S. (2007). Professional development for online teachers. In C. Cavanaugh \& R. Blomeyer (Eds.), What works in K-12 online learning (pp. 161-178). ISTE.

Martin, N. K., Sass, D. A., \& Schmitt, T. A. (2012). Teacher efficacy in student engagement, instructional management, student stressors, and burnout: A theoretical model using inclass variables to predict teachers' intent-to-leave. Teaching and Teacher Education, 28(4), 546-559. https://doi.org/10.1016/j.tate.2011.12.003

Mishra, P., \& Koehler, M. J. (2006). Technological pedagogical content knowledge: A framework for teacher knowledge. Teachers College Record, 108(6), 1017-1054. https://doi.org/10.1111/j.1467-9620.2006.00684.x

Moore-Hayes, C. (2011). Technology integration preparedness and its Influence on teacherefficacy. Canadian Journal of Learning and Technology / La revue canadienne de l'apprentissage et de la technologie, 37(3). https: / / doi.org/10.21432/T2B597

Niederhauser, D. S., \& Perkmen, S. (2010). Beyond self-efficacy: Measuring pre-service teachers' instructional technology outcome expectations. Computers in Human Behavior, 26(3), 436-442. https://doi.org/10.1016/j.chb.2009.12.002

Northcote, M., Gosselin, K. P., Reynaud, D., Kilgour, P., \& Anderson, M. (2015). Navigating learning journeys of online teachers: Threshold concepts and self-efficacy. Issues in Educational Research, 25(3), 319-344. https://www.iier.org.au/iier25/northcote.pdf 
Ontario College of Teachers. (2021). Additional qualifications.

https://www.oct.ca/members/additional-qualifications

Panisoara, I. O., Lazar, I., Panisoara, G., Chirca, R., \& Ursu, A. S. (2020). Motivation and continuance intention towards online instruction among teachers during the COVID-19 pandemic: The mediating effect of burnout and technostress. International Journal of Environmental Research and Public Health, 1721$)$. https://doi.org/10.3390/ijerph17218002

Perkmen, S. (2008). Factors that influence pre-service teachers' technology integration performance [Doctoral dissertation, lowa State University]. lowa State University Digital Repository. https: / / lib.dr.iastate.edu/cgi / viewcontent.cgi?article $=16803 \&$ context $=$ rtd

Pringle, J. (2020, April 29). Ontario cancels final exams for high schools. CTV News. https://tinyurl.com/ylu7r2ar

Rice, K. L. (2006). A comprehensive look at distance education in the K-12 context. Journal of Research on Technology in Education, 38(4), 425-448. https://doi.org/10.1080/15391523.2006.10782468

Robinia, K. A., \& Anderson, M. L. (2010). Online teaching efficacy of nurse faculty. Journal of Professional Nursing, 26, 168-175. https://doi.org/10.1016/j.profnurs.2010.02.006

Sang, G., Valcke, M., Tondeur, J., Zhu, C., \& van Braak, J. (2012). Exploring the educational beliefs of primary education student teachers in the Chinese context. Asia Pacific Education Review, 13(3), 417-425. https://doi.org/10.1007/s12564-012-9206-0

Schnackenberg, H., \& Still, G. (2014). Teacher preparation programs and technology integration: Best practices for curriculum design. International Journal of Education and Practice, 2(7), 147-158. https://doi.org/10.18488/journal.61/2014.2.7/61.7.147.158

Semiz, K., \& Ince, M. L. (2012). Pre-service physical education teachers' technological pedagogical content knowledge, technology integration self-efficacy and instructional technology outcome expectations. Australasian Journal of Educational Technology, 28(7). https://doi.org/10.14742/ajet.800

Shea, P. (2007). Bridges and barriers to teaching online college courses: A study of experienced online faculty in thirty-six colleges. Online Learning, $17(2)$. https://tinyurl.com/4eucy66x

Stein, M. K., \& Wang, M. C. (1988). Teacher development and school improvement: The process of teacher change. Teaching and Teacher Education, 4(2), 171-187. https://doi.org/10.1016/0742-051X(88)90016-9

Teo, T. (2014). Unpacking teachers' acceptance of technology: Tests of measurement invariance and latent mean differences. Computers \& Education, 75, 127-135. https://doi.org/10.1016/j.compedu.2014.01.014 
Tondeur, J., Van Braak, J., Ertmer, P. A., \& Ottenbreit-Leftwich, A. (2017). Understanding the relationship between teachers' pedagogical beliefs and technology use in education: A systematic review of qualitative evidence. Educational Technology Research and Development, 65(3), 555-575. https://doi.org/10.1007/s11423-016-9481-2

Tondeur, J., Van Braak, J., Sang, G., Voogt, J., Fisser, P., \& Ottenbreit-Leftwich, A. (2012). Preparing pre-service teachers to integrate technology in education: A synthesis of qualitative evidence. Computers \& Education, 59(1), 134-144.

https://doi.org/10.1016/j.compedu.2011.10.009

Tracz, S. M., \& Gibson, S. (1986, November 13-14). Effects of efficacy on academic achievement [Paper presentation]. Annual Meeting of the California Educational Research Association, Marina del Rey, CA, United States.

Tschannen-Moran, M., \& Hoy, A. W. (2001). Teacher efficacy: Capturing an elusive construct. Teaching and Teacher Education, 17(7), 783-805. https://doi.org/10.1016/S0742$051 \times(01) 00036-1$

Tschannen-Moran, M., Woolfolk Hoy, A., \& Hoy, W. K. (1998). Teacher efficacy: Its meaning and measure. Review of Educational Research, 68(2), 202-248. https://doi.org/10.3102\%2F00346543068002202

van Oostveen, R., Desjardins, F., \& Bullock, S., (2018). Professional development learning environments (PDLEs) embedded in a collaborative online learning environment (COLE): Moving towards a new conception of online professional learning. Education and Information Technologies, 24, 1863-1900. https://doi.org/10.1007/s10639-018-9686-6 